\title{
A PTPN11 mutation in a woman with Noonan syndrome and protein-losing enteropathy
}

\author{
Na Wang ${ }^{1}$, Wen Shi ${ }^{2}$ and Yang Jiao $^{3^{*}}$ (D)
}

\begin{abstract}
Background: Noonan syndrome is an autosomal dominant, variably expressed multisystem disorder characterized by specific facial and cardiac defects, delayed growth, ectodermal abnormalities, and lymphatic dysplasias. Lymphedema and chylous pleural effusions are common in Noonan syndrome, but protein-losing enteropathy (PLE) has only rarely been described in the condition and little is known about its genetic associations.

Case presentation: We report the case of a 30-year-old Chinese woman who developed severe recurrent edema and hypoproteinemia. Gastroduodenoscopy showed a "snowflake" appearance of lymphangiectasia in the duodenum, and $C T$ reconstruction of the small intestine showed segmental thickening of the intestinal wall with localized stenosis. Whole exome sequencing revealed that the patient harbored a pathogenic variant of PTPN11 (c.A922G p.N308D), which was unfortunately inherited by her 2.5-year-old daughter who had short stature and atrial septal defect but no hypoproteinemia.

Conclusions: This case of Noonan syndrome with PLE was associated with a PTPN11 mutation. A comprehensive review of PLE in Noonan syndrome revealed that PLE often presents late in this context but there is no clear genotype-phenotype correlation. Genetic evaluation with next-generation sequencing can be useful for securing the diagnosis and planning early intervention and management.
\end{abstract}

Keywords: Noonan syndrome, Protein-losing enteropathy, PTPN11, Hypoproteinemia

\section{Background}

Noonan syndrome (MIM: 163950) is an autosomal dominant, variably expressed multisystem disorder characterized by specific facies, cardiac defects, delayed growth, auditory deficits, ectodermal abnormalities, and lymphatic dysplasias $(<20 \%)$ [1]. While lymphedema and chylous pleural effusions are common in Noonan syndrome [2], protein-losing enteropathy (PLE) has rarely been reported and little is known about its genetic causes or associations in this context [3, 4]. PLE is usually syndromic or associated with non-syndromic primary intestinal lymphangiectasia. On its own, PLE has been reported in association with specific genetic mutations including in CCEB1, FAT4 [5], PIEZO1 [6], FOXC2 [7], CD55 [8], and DAGT [9].

Recent high-throughput genetic analyses with genome-wide association studies (GWAS) and whole exome sequencing (WES) have revealed a number of genetic variations that contribute to the susceptibility of Noonan syndrome [1]. All the genes currently implicated in Noonan syndrome encode proteins integral to the RAS-MAPK pathway, an important signal transduction pathway controlling cellular proliferation, differentiation, survival, and metabolism, with specific disease-causing mutations usually determining the Noonan subphenotype. In particular, patients carrying variants of

\footnotetext{
* Correspondence: peterpumch@163.com

${ }^{3}$ Department of General Internal Medicine, Peking Union Medical College Hospital, Chinese Academy of Medical Sciences \& Peking Union Medical College, No. 1, Shuaifuyuan, Wangfujing St. Beijing, Beijing 100730, China Full list of author information is available at the end of the article
}

(c) The Author(s). 2020 Open Access This article is distributed under the terms of the Creative Commons Attribution 4.0 International License (http://creativecommons.org/licenses/by/4.0/), which permits unrestricted use, distribution, and reproduction in any medium, provided you give appropriate credit to the original author(s) and the source, provide a link to the Creative Commons license, and indicate if changes were made. The Creative Commons Public Domain Dedication waiver (http://creativecommons.org/publicdomain/zero/1.0/) applies to the data made available in this article, unless otherwise stated. 
PTPN11 (roughly 50\%), an upstream member of the MAPK signaling cascade, tend to have pulmonary stenosis, short stature, lower IGF1 concentrations [10], bleeding diatheses, and juvenile myelomonocytic leukemia [11]. Patients harboring RAF1 (roughly 10\%) variants in serine 259 and serine 621 have hypertrophic cardiomyopathy $[12,13]$, and those with $K R A S(<2 \%)$ variants have delayed cognitive development [14] and intellectual disability [15]. Patients with SOS1 variants ( $10 \%$ ) have a higher prevalence of ectodermal abnormalities [16] and are taller than average [17], and those with NRAS mutations account for $<2 \%$ of cases and currently do not have a discernible genotype-phenotype correlation [18]. However, the association between PLE and specific genetic mutations in Noonan syndrome has yet to be determined.

Here we present the case of a 30-year-old Chinese woman presenting with recurrent edema and hypoproteinemia. Using WES and Sanger sequencing, we discovered that the patient carried the common pathogenic PTPN11 variant (c.A922G p.N308D) of Noonan syndrome. Unfortunately, screening of family members revealed the same mutation in her two and a half-year-old daughter. Her daughter had a relatively mild phenotype with facial dysmorphia and short stature. This case provides the opportunity to review the clinical features and genetics of PLE in Noonan syndrome and highlights the importance of mutation testing, genetic counselling, and family member screening to provide early intervention.

\section{Case presentation}

A 30-year-old woman was admitted to hospital with progressive lower limb edema over 8 months and occasional convulsions. She had initially ignored the bilateral lower limb edema but, as the edema gradually expanded to the abdomen, upper limbs, and even head and face, she was admitted to the local hospital for treatment of hypoproteinemia (albumin $21 \mathrm{~g} / \mathrm{L}$; normal range $35-52 \mathrm{~g} / \mathrm{L}$ ) and hypocalcemia (calcium $1.93 \mathrm{mmol} / \mathrm{L} ; 2.13-2.70 \mathrm{mmol} / \mathrm{L}$ ). However, no diagnosis was made, and she was eventually referred to the tertiary hospital. She reported a past medical history of tetralogy of Fallot at 7 years of age, for which she underwent surgery at age 14 . Her menstrual cycle was normal, and she had given birth to a daughter. Her child, who was two and a half years old at presentation, was born normal but had a history of feeding difficulties and atrial septal defect. There was no other family history of note.

Upon admission, the patient was conscious and her vital signs were within normal limits. She was $150.1 \mathrm{~cm}$ tall and weighed $55 \mathrm{~kg}$, and her daughter showed short stature (height $132.5 \mathrm{~cm},-3.6 \mathrm{SD}$ ). They shared the same dysmorphic facies with hypertelorism, low-set ears, and a posterior hairline. Limb circumferences were 24.5 and
$25 \mathrm{~cm}$ at $10 \mathrm{~cm}$ above the upper edge of the patella and 14 and $13.5 \mathrm{~cm}$ at $10 \mathrm{~cm}$ below the edge of the patella. In addition, early grade 3 diastolic murmurs were audible over the pulmonary and tricuspid valves.

Thorough biochemical screening was performed. Unsurprisingly, many nutritional indices were reduced beyond the lower limit of normal values except for liver function and renal function. The lymphocyte count was $0.29 \times 10^{9} / \mathrm{L} \quad\left(0.80-4.00 \times 10^{9} / \mathrm{L}\right) ;$ hemoglobin $108 \mathrm{~g} / \mathrm{L}$ $(110-150 \mathrm{~g} / \mathrm{L})$; total protein $31 \mathrm{~g} / \mathrm{L}(60-85 \mathrm{~g} / \mathrm{L})$; albumin $19 \mathrm{~g} / \mathrm{L} \quad(35-52 \mathrm{~g} / \mathrm{L}) ;$ calcium $1.33 \mathrm{mmol} / \mathrm{L}$ (corrected calcium $1.77 \mathrm{mmol} / \mathrm{L} ; 2.13-2.70 \mathrm{mmol} / \mathrm{L}$ ). All immunoglobulins were decreased.

In view of the definite diagnosis of hypoproteinemia, the digestive, endocrine, and cardiac systems were next screened in detail. For the digestive system, a stool occult blood test was positive and the D-xylose absorption test was $0.9 \mathrm{~g} / 5 \mathrm{~h}$ (normal >1.2). Gastroduodenoscopy showed a snowflake appearance in the duodenum (Fig. 1a and b), a sign of lymphangiectasia. CT reconstruction of the small intestine showed that the descending duodenum wall was coarsely thickened and the small intestinal wall was sectionally thickened, enhanced, and locally narrowed (Fig. 1c and d). There was no obvious colonic abnormality.

Lymphatic imaging of the lower limbs showed lymphangiectasis and bilateral widening of the venous angle in the mediastinum. Imaging at $1.5 \mathrm{~h}$ showed diffuse radioactive uptake in the small intestine, which diminished by 5 hours but at which time showed new areas of radioactive uptake in the ascending colon. Whole body lymphatic imaging indicated widening of the lymphatics in both lower limbs and a flaky radioactive enhancement shadow was seen in the abdominal cavity within $3 \mathrm{~h}$. By $6 \mathrm{~h}$, the hepatic flexure and transverse colon could be visualized.

In the light of paroxysmal tetany, endocrine system screening mainly focused on metabolic indicators. Parathyroid hormone levels were $122.20 \mathrm{pg} / \mathrm{ml}$ (12.0-68.0 $\mathrm{pg} / \mathrm{ml}$ ), synchronous blood calcium was $1.55 \mathrm{mmol} / \mathrm{L}$, synchronous albumin was $19 \mathrm{~g} / \mathrm{L}$, synchronous $24 \mathrm{~h}$ urine calcium was $0.10 \mathrm{mmol} / 24 \mathrm{~h}$, total 24-hydroxyvitamin D was $<3.00 \mathrm{ng} / \mathrm{ml}(8.0-50.0 \mathrm{ng} / \mathrm{ml}), 1,25$-dihydroxyvitamin D3 was $24.42 \mathrm{pg} / \mathrm{ml}(19.6-54.3 \mathrm{pg} / \mathrm{ml})$, blood magnesium was $0.45 \mathrm{mmol} / \mathrm{L}(0.70-1.10 \mathrm{mmol} / \mathrm{L})$, and $\beta$-collagen degradation product was $1.23 \mathrm{ng} / \mathrm{ml}(0.21-0.44 \mathrm{ng} / \mathrm{ml})$. Echocardiography revealed no abnormality in cardiac structure or function except for changes associated with the previous repair.

The diagnosis remained uncertain, so the patient and family agreed to whole exome sequencing. A pathogenic variant in PTPN11 (c.A922G p.N308D) was detected and confirmed by Sanger sequencing, which also revealed the same mutation in the patient's daughter 

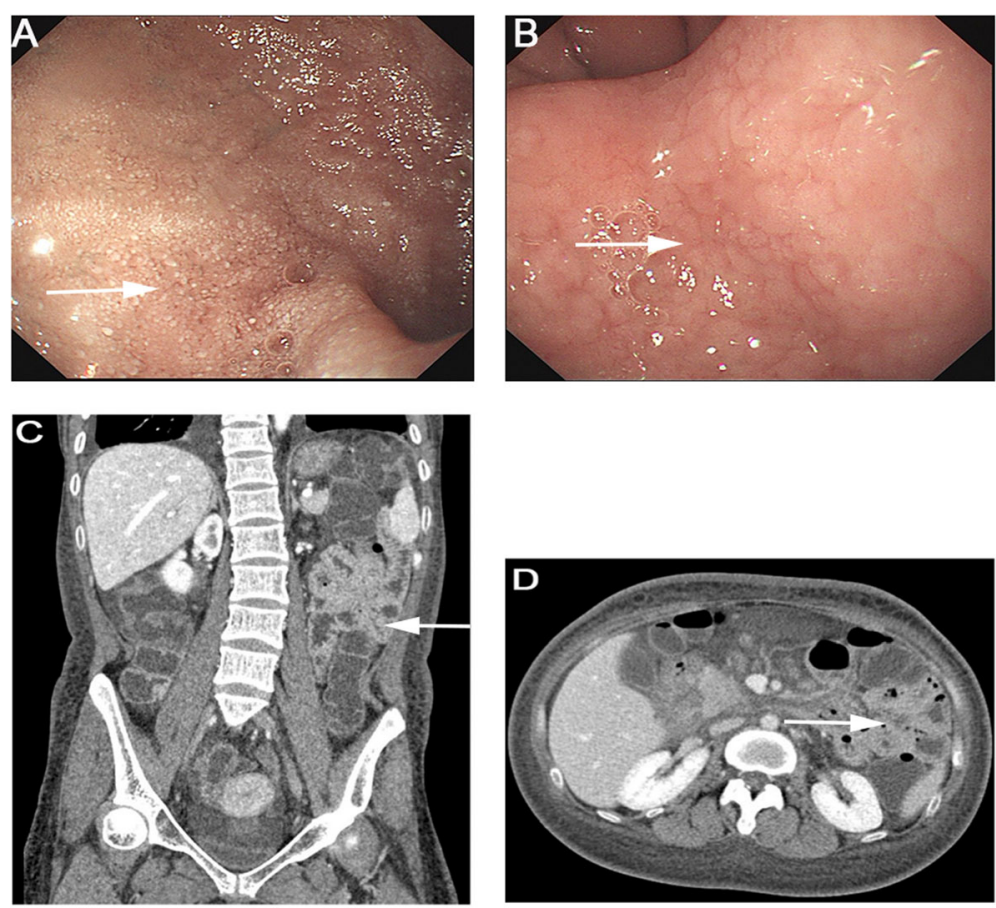

Fig. 1 a shows the snowflake appearance of the duodenum and $\mathbf{b}$ shows the granuloid changes in the gastric antral mucosa by electronic gastroscopy. Reconstructive CT of the small intestine in $(\mathbf{c} \& \mathbf{d})$ demonstrate segmental thickening of the intestinal wall with local intestinal stenosis. Arrows highlight the indicated features

(Fig. 2a \& b). No mutation was detected in the patient's mother, and the father had died some years before from cardiovascular disease.

The patient was prescribed a medium-chain triglyceride diet. Example dietary changes included the use of 3$4 \mathrm{~g} /$ day coconut oil for cooking rather than the intake of long-chain fats; increased intake of high-quality proteins like egg white, skimmed milk, whey protein, and lean meat; and avoidance of crude fiber (e.g., grains, celery) and high-fat food (e.g., cream, fatty pork). In the following 8 months, there were no further episodes of edema or convulsions with periodic infusion of albumin and
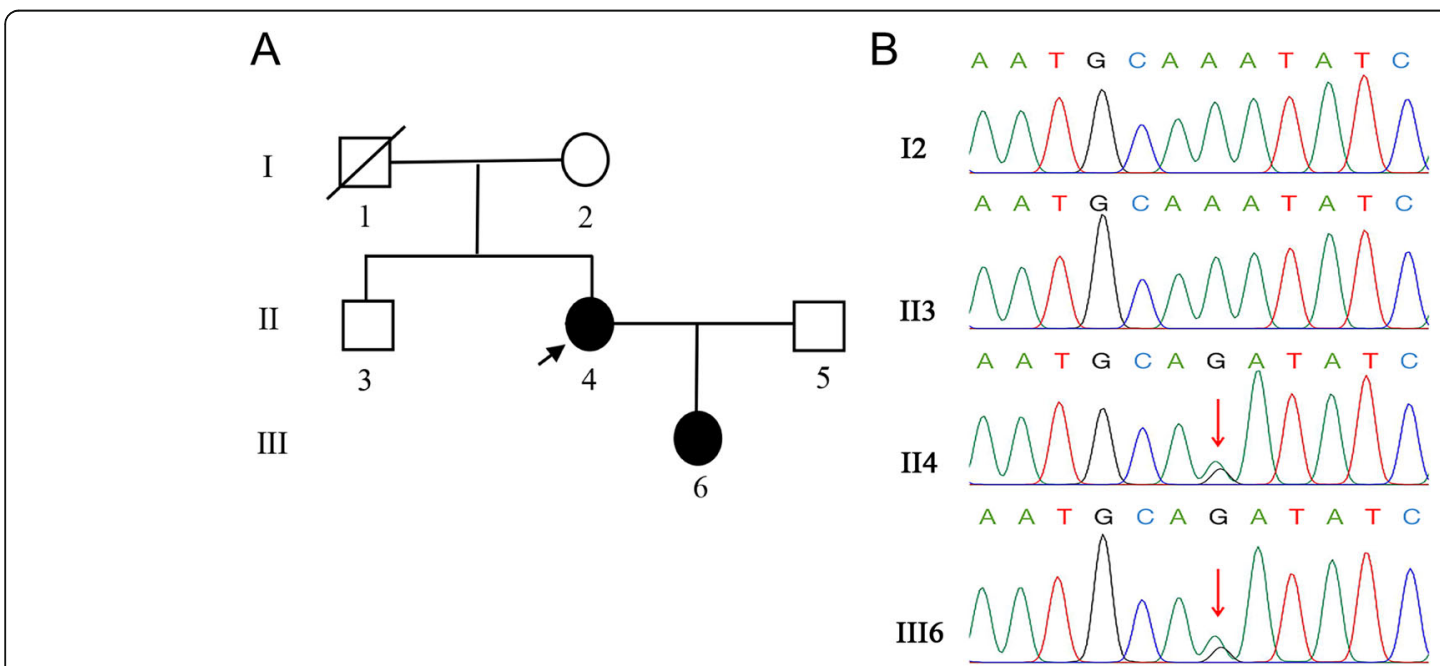

Fig. 2 a shows the pedigree of the patient's family. Patients are represented in black and the arrow represents the proband, which is the patient discussed in this article. $\mathbf{b}$ shows the Sanger sequencing of the PTPN11 gene in the family. A missense mutation was found in PTPN11 (c.A922G p.N308D) of the patient (II4), which was inherited by her daughter (III6). The patient's father died of acute cerebrovascular disease before genetic testing 
oral calcium intake. Her daughter was short and met the criteria for taking growth hormone replacement. Regular follow-up of the daughter was also advised.

\section{Discussion and conclusions}

Here we describe a patient with severe edema and tetany developing over a long timeframe. There was no obvious cause for her diffuse lymphangiectasia, but clinical observation revealed abnormal facies and she had a history of congenital heart disease, raising suspicion of a congenital abnormality. However, next-generation sequencing was required to confirm the presence of a pathogenic PTPN11 mutation to explain congenital heart disease and PLE. The genotype-phenotype correlation of Noonan syndrome and PLE has not been established. The occurrence or severity of lymphatic abnormality might differ according to the specific genetic mutation, but data on this hypothesis is lacking.

A comprehensive literature search of the PubMed and CNKI databases from 1972 to 2019 using the search terms "Noonan syndrome, protein-losing enteropathy" and "Noonan syndrome, PTPN11" revealed only nine reported cases (Table 1). Male and female patients with Noonan syndrome who developed PLE were similarly affected. However, patients usually developed PLE after Noonan syndrome was diagnosed $(16.4 \pm 7.9$ vs. $7.3 \pm$ 7.1 years; $p=0.03$ ), and our patient's daughter will require long-term follow-up to anticipate the development of this complication. All patients had congenital heart disease, two of whom had tetralogy of Fallot, a rare cardiac abnormality [4]. Other common manifestations were edema $(6 / 8,75 \%)$ and hypoalbuminemia $(8 / 8$; total protein $33.6 \pm 7.9 \mathrm{~g} / \mathrm{L}$; albumin $18.9 \pm 3.6 \mathrm{~g} / \mathrm{L}$ ). Other isolated clinical manifestations included hepatomegaly [21], intractable bleeding from cutaneous lymphatic malformations [25], drug reactions with eosinophilia and systemic symptoms (DRESS), and thrombotic microangiopathy [26]. Our patient demonstrated occasional tetany due to hypocalcemia, which was treatable with calcium supplements. In the published cases, two patients died of severe complications: one of heart failure and another of hemorrhagic pancreatitis after a valvuloplasty.

PTPN11 encodes the protein tyrosine phosphatase SHP-2, which has an amino N-SH2 domain and a phosphotyrosine phosphatase domain (PTP) to switch the protein between its inactive and active conformations [1]. The N-SH2 domain plays a key role in maintaining inactive SHP-2 [27], with the N-SH2 and PTP domains sharing a broad interaction surface. Several hydrogen bonds between the N-SH2/PTP domains form the most critical catalytic sites. Alterations in these critical amino acids might disturb the equilibrium between active and inactive forms of SHP-2 [28]. Indeed, the $\mathrm{G}>\mathrm{C}$ point mutation at position 417 (Glu139Asp) is the only mutation identified which alters an amino acid in the C$\mathrm{SH} 2$ domain, which contributes to substrate specificity and binding affinity [28].

An energetics-based structural analysis indicated that a gain-of-function mutation in PTPN11 could be responsible for the disease [29]. There are 40 reported PTPN11 mutations (UniProt.org; Fig. 3), and several large retrospective studies have indicated that different PTPN11 mutations are correlated with some sub-phenotypes. Musante et al. [28] screened for mutations in PTPN11 in 96 familial and sporadic cases and found that the phenotypes associated with PTPN11 mutations included (from the most to least common) dysmorphic features (hypertelorism, low-set ears, down-slanting palpebral fissures), cryptorchidism, short stature, cardiac defects, and myelodysplasia. In another large retrospective study [29], the variant was found to be more frequent in familial cases than sporadic cases. Genotype-phenotype correlation analysis revealed that pulmonary stenosis was more prevalent in subjects with Noonan syndrome with PTPN11 mutations than those without $(70.6 \%$ vs. $46.2 \%$; $p<0.01)$. Furthermore, a pathogenic PTPN11 mutation was predicted to confer a 3.5 -fold increased risk of developing cancer compared with the general population [30]. In a Japanese study of 41 Noonan syndrome patients, mutations at codons $61,71,72$, and 76 were frequently identified in patients with leukemia, including those with JMML, MDS, AML, and ALL [31]. In terms of other disease associations, three different PTPN11 mutations (E69K, T507K, and $\mathrm{Y} 62 \mathrm{C}$ ) were identified in 89 primary neuroblastomas [32] and, in a case report, a patient with Noonan syndrome caused by a germline mutation in exon 13 of PTPN11 (c1507G > C, p.Gly503Arg) developed Hodgkin's lymphoma [33], which was also associated with congenital refractory chylothorax and subcutaneous edema [34].

With respect to PTPN11 mutations in Noonan syndrome, Joyce et al. [24] identified PTPN11 (c.181G > A, p.Asp61Asn) and PTPN11 (c.188A > G, p.Tyr63Cys) mutations in two Noonan syndrome patients with PLE. Interestingly, Noonan syndrome and cardiofaciocutaneous syndrome (CFC) are both RASopathies that share some similarities including the same genetic variants [35]. Joyce et al. [24] also reported three patients with CFC-PLE carrying KRAS (c.178G > C, p.Gly60Arg), $B R A F$ (c.770A > G, p.Gln257Arg), and RIT1 (c.246 T > G, p.Phe82Leu) mutations. Whether the PTPN11 mutation or the N308D variant is causal for PLE remains to be determined, but other lymphatic disorders have been reported in association with PTPN11 mutations, including jugular lymphatic obstruction with a heterozygous $\mathrm{T}>\mathrm{C}$ change in exon 8 [36] and lymphatic dysplasia in the lung and mesentery with a heterozygous mutation at G503R [37]. Interestingly, the N308D mutation is 
Table 1 Summary of all patients with Noonan syndrome-associated PLE identified in the literature (1972-2019)

\begin{tabular}{|c|c|c|c|c|c|c|c|c|c|c|}
\hline Cases & Sex & $\begin{array}{l}\text { The onset } \\
\text { of NS (yr) }\end{array}$ & $\begin{array}{l}\text { The } \\
\text { onset } \\
\text { of PLE } \\
\text { (yr) }\end{array}$ & Symptoms & $\begin{array}{l}\text { Cardiac } \\
\text { disorder }\end{array}$ & $\begin{array}{l}\mathrm{TP} \\
(\mathrm{g} / \mathrm{L})\end{array}$ & $\begin{array}{l}\text { Alb } \\
(\mathrm{g} / \mathrm{L})\end{array}$ & $\begin{array}{l}\text { Transnodal } \\
\text { lymphangiography }\end{array}$ & Treatments & Follow-up \\
\hline $\begin{array}{l}\text { Matsumoto } \\
\text { et al. [19] }\end{array}$ & $F$ & 17 & 17 & $\begin{array}{l}\text { No obvious } \\
\text { clinical } \\
\text { symptoms }\end{array}$ & $\mathrm{HCM}$ & 31 & 15 & $\begin{array}{l}\text { Absent thoracic duct } \\
\text { abdominal collateral } \\
\text { lymphatics and bilateral } \\
\text { iliac lymphangiectasia }\end{array}$ & $\begin{array}{l}\text { Steroid therapy (1 } \\
\mathrm{mg} / \mathrm{kg} / \mathrm{d}) \text { Low-fat, } \\
\text { protein-rich diet } \\
\text { supplemented } \\
\text { with medium- } \\
\text { chain triglycerides }\end{array}$ & Relieved \\
\hline $\begin{array}{l}\text { Mizuochi } \\
\text { et al. [20] }\end{array}$ & $\mathrm{F}$ & 1.5 & 8 & $\begin{array}{l}\text { Edema, } \\
\text { abdominal } \\
\text { pain, } \\
\text { diarrhea }\end{array}$ & ASD PVS & 32 & 18 & & $\begin{array}{l}\text { Spironolactone } \\
(2.5 \mathrm{mg} / \mathrm{kg} / \mathrm{d}) \\
\text { Furosemide }(2.0 \\
\mathrm{mg} / \mathrm{kg} / \mathrm{d})\end{array}$ & Relieved \\
\hline $\begin{array}{l}\text { Keberle } \\
\text { et al. [4] }\end{array}$ & M & 6 & 13 & $\begin{array}{l}\text { Edema of } \\
\text { abdomen } \\
\text { and } \\
\text { hydrocele } \\
\text { testis }\end{array}$ & ASD PVS & 32 & 18 & $\begin{array}{l}\text { Protein loss from the } \\
\text { small intestine }\end{array}$ & $\begin{array}{l}\text { Albumin }(2.5 \mathrm{~g}) \\
\text { Growth hormone }\end{array}$ & Relieved \\
\hline $\begin{array}{l}\text { Keberle } \\
\text { et al. [4] }\end{array}$ & M & 19 & 21 & $\begin{array}{l}\text { Tibial } \\
\text { edema } \\
\text { Clubbing }\end{array}$ & $\begin{array}{l}\text { Fallot's } \\
\text { tetralogy }\end{array}$ & 41 & 26 & $\begin{array}{l}\text { Intestinal protein loss } \\
\text { predominantly in the } \\
\text { ileum }\end{array}$ & $\begin{array}{l}\text { Low-fat, protein- } \\
\text { rich diet, medium- } \\
\text { chain triglycerides }\end{array}$ & Relieved \\
\hline $\begin{array}{l}\text { O'Sullivan } \\
\text { et al. [21] }\end{array}$ & M & 7 & 22 & Diarrhea & PVS & $<20$ & & & Anti-heart failure & Died $^{a}$ \\
\hline $\begin{array}{l}\text { Herzog } \\
\text { et al. [22] }\end{array}$ & $\mathrm{F}$ & 0.9 & 15 & $\begin{array}{l}\text { Ankle } \\
\text { swelling }\end{array}$ & ASD PVS & 45 & & $\begin{array}{l}\text { Hypoplasia of the } \\
\text { lymphatics of the } \\
\text { extremity and multiple } \\
\text { ectatic lymph vessels in } \\
\text { the mediastinal area and } \\
\text { right supraclavicular area }\end{array}$ & $\begin{array}{l}\text { Medium-chain } \\
\text { triglyceride diet }\end{array}$ & Relieved \\
\hline $\begin{array}{l}\text { Vallet } \\
\text { et al. [23] }\end{array}$ & M & 0.3 & 6 & $\begin{array}{l}\text { Diarrhea } \\
\text { Anasarca, } \\
\text { chylorrhea } \\
\text { from the } \\
\text { inguinal } \\
\text { skin }\end{array}$ & PVS & 38 & 20 & Unavailable & $\begin{array}{l}\text { Medium-chain triglycerides and a } \\
\text { low-fat diet }\end{array}$ & Died $^{\mathrm{b}}$ \\
\hline $\begin{array}{l}\text { Joyce } \\
\text { et al. [24] }\end{array}$ & $\mathrm{F}$ & Unavailable & 27 & $\begin{array}{l}\text { Bilateral } \\
\text { lower limb } \\
\text { and genital } \\
\text { swelling }\end{array}$ & PVS & Unavailable & Unavailable & $\begin{array}{l}\text { Lymph reflux/rerouting. } \\
\text { R: popliteal LN present. } \\
\text { Contrast in vulva and } \\
\text { multiple channels in } \\
\text { both legs }\end{array}$ & Low-fat MCT diet & Relieved \\
\hline $\begin{array}{l}\text { Joyce } \\
\text { et al. [24] }\end{array}$ & M & Unavailable & 55 & $\begin{array}{l}\text { Bilateral } \\
\text { lower limb } \\
\text { and } \\
\text { suprapubic } \\
\text { swelling }\end{array}$ & ASD & Unavailable & Unavailable & Unavailable & Unavailable & Unavailable \\
\hline Our case & $\mathrm{F}$ & 7 & 30 & $\begin{array}{l}\text { Extrimitis } \\
\text { edema }\end{array}$ & $\begin{array}{l}\text { Fallot's } \\
\text { tetralogy }\end{array}$ & 31 & 19 & $\begin{array}{l}\text { Lymphangiectasis and } \\
\text { bilateral widening of the } \\
\text { venous angle in the } \\
\text { mediastinum and small } \\
\text { intestine }\end{array}$ & $\begin{array}{l}\text { Low-fat, medium- } \\
\text { chain triglycerides }\end{array}$ & Relieved \\
\hline
\end{tabular}

Abbreviations: PLE Protein-losing enteropathy, HCM Hypertrophic cardiomyopathy, ASD Atrial septal defect, PVS Pulmonary valve stenosis, TP Total protein, Alb Albumin; $a$ means the patient died of heart failure; $b$, the autopsy revealed the immediate cause of death to be hemorrhagic pancreatitis after a valvuloplasty for PVS. The normal range for TP and Alb is $60-85 \mathrm{~g} / \mathrm{L}$ and $35-52 \mathrm{~g} / \mathrm{L}$, respectively

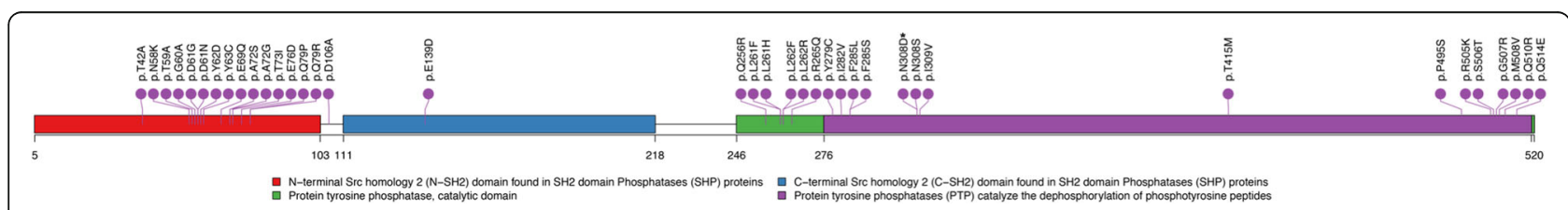

Fig. 3 Distribution of the missense mutations identified in PTPN11, as provided by the UniProt database (uniprot.org). The mutation detected in our patient is marked with an asterisk. The different colored rectangles represent the protein domains and the purple spheres represent amino acid changes at different mutation sites 
Table 2 Differential characteristics of three congenital diseases associated with PLE

\begin{tabular}{|c|c|c|c|c|c|c|}
\hline \multirow[t]{2}{*}{ Disease } & \multirow{2}{*}{$\begin{array}{l}\text { Genetic } \\
\text { property }\end{array}$} & \multirow[t]{2}{*}{ Causative genes } & \multirow[t]{2}{*}{ Morbidity } & \multirow[t]{2}{*}{ Pattern } & \multicolumn{2}{|l|}{ Height (cm) } \\
\hline & & & & & $M$ & $\mathrm{~F}$ \\
\hline $\begin{array}{l}\text { Hennekam } \\
\text { syndrome }\end{array}$ & $\begin{array}{l}\text { Recessive } \\
\text { inheritance }\end{array}$ & $\begin{array}{l}\text { CCEB1, FAT4, } \\
\text { ADAMTS3 }\end{array}$ & $\begin{array}{l}\text { Rare }<50 \\
\text { cases/ } \\
\text { worldwide }\end{array}$ & $\begin{array}{l}\text { Lymphangiogenesis can occur in many areas, the most } \\
\text { common being the small intestine but also the kidney, chest, } \\
\text { pericardium, thyroid gland and skin [39]. }\end{array}$ & $156.3 \pm 11.3$ & $155.3 \pm 4.7$ \\
\hline $\begin{array}{l}\text { Turner } \\
\text { syndrome }\end{array}$ & $\begin{array}{l}\text { Allosomal } \\
\text { inheritance }\end{array}$ & $\begin{array}{l}45, X \\
46, X, i(X q) \\
\text { Mosaicism }\end{array}$ & $\begin{array}{l}1 / 1500- \\
2500\end{array}$ & $\begin{array}{l}\text { Infants with a } 45, X \text { karyotype are the most likely to have } \\
\text { congenital lymphedema [40] }\end{array}$ & & $141.3 \pm 5.6$ \\
\hline $\begin{array}{l}\text { Noonan } \\
\text { syndrome }\end{array}$ & $\begin{array}{l}\text { Autosomal } \\
\text { dominant }\end{array}$ & $\begin{array}{l}\text { PTPN11, SOS1, } \\
\text { RAF1, KRAS, SHOC2, } \\
\text { NRAS }\end{array}$ & $\begin{array}{l}1 / 1000-1 / \\
2500\end{array}$ & $\begin{array}{l}\text { Lymphangiogenesis restricted to pterygium and limbal } \\
\text { lymphedema and often combined with cardiac disease. }\end{array}$ & $157.3 \pm 7.4$ & $146.8 \pm 6.9$ \\
\hline
\end{tabular}

Abbreviation: PLE Protein-losing enteropathy

frequently hereditary rather than sporadic. Tartaglia et al. [38] reported an $\mathrm{A} \rightarrow \mathrm{G}$ transition at position 922 in exon 8 in three families, as did Musante et al. [28] in another family. Our case further contributes to the evidence that this mutation clusters in families. While PLE has no clear genotype-phenotype correlation, there are certainly several cases suggesting that these mutations may be pathogenic; further work is needed in larger cohorts.

In our case, the patient carried the PTPN11 variant, which was inherited by her daughter. It was unclear whether this variant was inherited or sporadic (Fig. 3), although her father, who had died of acute cerebrovascular disease aged 55 years and could therefore not be tested, showed no clinical manifestations of Noonan syndrome.

There is no standard treatment for PLE in Noonan syndrome. Most patients reported in the literature recovered after treatment, which included periodic supplemental albumin and long-term medium-chain triglycerides. Moreover, glucocorticoids and diuretics achieved long-term symptomatic relief in some patients with Noonan syndrome [19, 20]. Systemic corticosteroids such as prednisone have been used for their antiinflammatory effects [39]. Diuretics may decrease the CVP, which promotes lymphangiogenesis and lymphangiectasia [40]. Early growth hormone replacement in children can result in near adult heights later in life [41].

PLE is often congenital in etiology and associated with Hennekam syndrome (HS), Turner syndrome (TS), and Noonan syndrome (Table 2). HS is a recessive disorder that can have disordered small intestinal lymphangiogenesis associated with mutations in CCBE1 and FAT4 $[42,43]$. TS is an allosomal disorder in which infants with the 45,X karyotype are most likely to have congenital lymphedema [44].

In conclusion, here we report a case of Noonan syndrome with PLE carrying a PTPN11 variant. PLE occurs late in patients with Noonan syndrome. Noonan syndrome may be confused with other genetic diseases clinically, and genetic evaluation with next-generation sequencing to identify the genetic basis can be helpful. Finally, screening family members, especially children, may provide the definitive diagnosis to guide early intervention.

\section{Abbreviations}

CT: Computed tomography; DRESS: Drug reactions with eosinophilia and systemic symptoms; GWAS: Genome-wide association studies; HS: Hennekam syndrome; MAPK: Mitogen activated protein kinase; PLE: Protein-losing enteropathy; TS: Turner syndrome; WES: Whole exome sequencing

\section{Acknowledgements \\ Not applicable.}

\section{Authors' contributions}

All authors were involved in the care of the patients. NW wrote the initial draft of the manuscript. WS and $Y J$ critically appraised and revised the overall content of the manuscript. All authors read and approved the final manuscript.

\section{Authors' information}

All authors are from Peking Union Medical College Hospital, Chinese Academy of Medical Sciences \& Peking Union Medical College, Beijing, China. NW is from the Department of Pulmonary and Critical Care Medicine, WS is from the Department of Gastroenterology, and YJ is from the Department of General Internal Medicine.

\section{Funding}

It is financially supported by Medical Education Quality Project 2019, Peking Union Medical College (2019zlgc0104). The funding body had no role in the design of the study and collection, analysis and interpretation of data, or in writing the manuscript.

\section{Availability of data and materials}

Data sharing is not applicable to this article as no datasets were generated or analyzed during the current study.

Ethics approval and consent to participate

Not applicable.

\section{Consent for publication}

Written informed consent was obtained from the patient for publication of this case report and any accompanying images.

\section{Competing interests}

The authors declare that they have no competing interests.

\section{Author details}

${ }^{1}$ Department of Pulmonary and Critical Care Medicine, Peking Union Medical College Hospital, Chinese Academy of Medical Sciences \& Peking Union 
Medical College, Beijing 100730, China. ${ }^{2}$ Department of Gastroenterology, Peking Union Medical College Hospital, Chinese Academy of Medical Sciences \& Peking Union Medical College, Beijing 100730, China. ${ }^{3}$ Department of General Internal Medicine, Peking Union Medical College Hospital, Chinese Academy of Medical Sciences \& Peking Union Medical College, No. 1, Shuaifuyuan, Wangfujing St. Beijing, Beijing 100730, China.

\section{Received: 13 September 2019 Accepted: 10 February 2020}

\section{1.}

\section{References}

1. Roberts AE, Allanson JE, Tartaglia M, Gelb BD. Noonan syndrome. Lancet. 2013;381(9863):333-42.

2. Lanning P, Simila S, Suramo I, Paavilainen T. Lymphatic abnormalities in Noonan's syndrome. Pediatr Radiol. 1978;7(2):106-9.

3. Hasegawa K, Nagaoka Y, Maruyama H, Aya K, Tanaka H, Morishima T. Lateonset lymphedema and protein-losing Enteropathy with Noonan syndrome. Clin Pediatr Endocrinol. 2009;18(3):87-93.

4. Keberle M, Mork H, Jenett M, Hahn D, Scheurlen M. Computed tomography after lymphangiography in the diagnosis of intestinal lymphangiectasia with protein-losing enteropathy in Noonan's syndrome. Eur Radiol. 2000;10(10): $1591-3$.

5. Van Balkom ID, Alders M, Allanson J, Bellini C, Frank U, De Jong G, et al. Lymphedema-lymphangiectasia-mental retardation (Hennekam) syndrome: a review. Am J Med Genet. 2002;112(4):412-21.

6. Fotiou E, Martin-Almedina S, Simpson MA, Lin S, Gordon K, Brice G, et al. Novel mutations in PIEZO1 cause an autosomal recessive generalized lymphatic dysplasia with non-immune hydrops fetalis. Nat Commun. 2015;6: 8085.

7. Fang J, Dagenais SL, Erickson RP, Arlt MF, Glynn MW, Gorski JL, et al. Mutations in FOXC2 (MFH-1), a forkhead family transcription factor, are responsible for the hereditary lymphedema-distichiasis syndrome. Am J Hum Genet. 2000;67(6):1382-8.

8. Irrthum A, Devriendt K, Chitayat D, Matthijs G, Glade C, Steijlen PM, et al. Mutations in the transcription factor gene SOX18 underlie recessive and dominant forms of hypotrichosis-lymphedema-telangiectasia. Am J Hum Genet. 2003;72(6):1470-8.

9. van Rijn JM, Ardy RC, Kuloglu Z, Harter B, van Haaften-Visser DY, van der Doef HPJ, et al. Intestinal failure and aberrant lipid metabolism in patients with DGAT1 deficiency. Gastroenterology. 2018;155(1):130-43 e115.

10. Bertelloni S, Baroncelli Gl, Dati E, Ghione S, Baldinotti F, Toschi B, et al. IGF-I generation test in prepubertal children with Noonan syndrome due to mutations in the PTPN11 gene. Hormones. 2013;12(1):86-92.

11. Strullu M, Caye A, Lachenaud J, Cassinat B, Gazal S, Fenneteau O, et al. Juvenile myelomonocytic leukaemia and Noonan syndrome. J Med Genet. 2014:51(10):689-97.

12. Pandit B, Sarkozy A, Pennacchio LA, Carta C, Oishi K, Martinelli S, et al. Gainof-function RAF1 mutations cause Noonan and LEOPARD syndromes with hypertrophic cardiomyopathy. Nat Genet. 2007;39(8):1007-12.

13. Tartaglia M, Zampino G, Gelb BD. Noonan syndrome: clinical aspects and molecular pathogenesis. Mol Syndromol. 2010;1(1):2-26.

14. Carta C, Pantaleoni F, Bocchinfuso G, Stella L, Vasta I, Sarkozy A, et al. Germline missense mutations affecting KRAS isoform $B$ are associated with a severe Noonan syndrome phenotype. Am J Hum Genet. 2006; 79(1):129-35.

15. Zenker M, Lehmann K, Schulz AL, Barth H, Hansmann D, Koenig R, et al. Expansion of the genotypic and phenotypic spectrum in patients with KRAS germline mutations. J Med Genet. 2007;44(2):131-5.

16. Tartaglia M, Pennacchio LA, Zhao C, Yadav KK, Fodale V, Sarkozy A, et al. Gain-of-function SOS1 mutations cause a distinctive form of Noonan syndrome. Nat Genet. 2007;39(1):75-9.

17. Shoji Y, Ida S, Niihori T, Aoki Y, Okamoto N, Etani Y, et al. Genotypephenotype correlation analysis in Japanese patients with Noonan syndrome. Endocr J. 2019;66(11):983.

18. Cirstea IC, Kutsche K, Dvorsky R, Gremer L, Carta C, Horn D, et al. A restricted spectrum of NRAS mutations causes Noonan syndrome. Nat Genet. 2010; 42(1):27-9.

19. Matsumoto T, Kudo T, Endo J, Hashida K, Tachibana N, Murakoshi T, et al. Transnodal lymphangiography and post-CT for protein-losing enteropathy in Noonan syndrome. Minim Invasive Ther Allied Technol. 2015;24(4):246-9.
20. Mizuochi T, Suda K, Seki Y, Yanagi T, Yoshimoto H, Kudo Y, et al. Successful diuretics treatment of protein-losing enteropathy in Noonan syndrome. Pediatr Int. 2015;57(2):e39-41.

21. O'Sullivan T, Hally M, Cronin CC, Bashyam M, Mitchell TH. Constrictive pericarditis simulating intestinal lymphangiectasia in a patient with the Noonan syndrome. Ir J Med Sci. 1993;162(5):180-1.

22. Herzog DB, Logan R, Kooistra JB. The Noonan syndrome with intestinal lymphangiectasia. J Pediatr. 1976;88(2):270-2.

23. Vallet $\mathrm{HL}$, Holtzapple PG, Eberlein WR, Yakovac WC, Moshang T Jr, Bongiovanni AM. Noonan syndrome with intestinal lymphangiectasis. A metabolic and anatomic study. J Pediatr. 1972;80(2):269-74.

24. Joyce S, Gordon K, Brice G, Ostergaard P, Nagaraja R, Short J, et al. The lymphatic phenotype in Noonan and Cardiofaciocutaneous syndrome. Eur J Hum Genet. 2016;24(5):690-6.

25. Baumann BC, MacArthur KM, Rosenbach M, Miller JC, Ben-Josef E. Effective palliation of intractable bleeding from Noonan syndrome-associated lymphatic malformations by radiotherapy. Acta Derm Venereol. 2015;95(8): 1009-10.

26. Bobot M, Coen M, Simon C, Daniel L, Habib G, Serratrice J. DRESS syndrome with thrombotic microangiopathy revealing a Noonan syndrome: case report. Medicine (Baltimore). 2018;97(15):e0297.

27. Hof P, Pluskey S, Dhe-Paganon S, Eck MJ, Shoelson SE. Crystal structure of the tyrosine phosphatase SHP-2. Cell. 1998:92(4):441-50.

28. Musante L, Kehl HG, Majewski F, Meinecke P, Schweiger S, GillessenKaesbach $\mathrm{G}$, et al. Spectrum of mutations in PTPN11 and genotypephenotype correlation in 96 patients with Noonan syndrome and five patients with cardio-facio-cutaneous syndrome. Eur J Hum Genet. 2003; 11(2):201-6.

29. Tartaglia M, Kalidas K, Shaw A, Song X, Musat DL, van der Burgt I, et al. PTPN11 mutations in Noonan syndrome: molecular spectrum, genotypephenotype correlation, and phenotypic heterogeneity. Am J Hum Genet. 2002;70(6):1555-63.

30. Jongmans MC, van der Burgt I, Hoogerbrugge PM, Noordam K, Yntema HG, Nillesen WM, et al. Cancer risk in patients with Noonan syndrome carrying a PTPN11 mutation. Eur J Hum Genet. 2011;19(8):870-4.

31. Niihori T, Aoki Y, Ohashi H, Kurosawa K, Kondoh T, Ishikiriyama S, et al. Functional analysis of PTPN11/SHP-2 mutants identified in Noonan syndrome and childhood leukemia. J Hum Genet. 2005;50(4):192-202.

32. Bentires-Alj M, Paez JG, David FS, Keilhack H, Halmos B, Naoki K, et al. Activating mutations of the Noonan syndrome-associated SHP2/PTPN11 gene in human solid tumors and adult acute myelogenous leukemia. Cancer Res. 2004;64(24):8816-20.

33. Lo FS, Kuo TT, Wang CJ, Kuo MT, Kuo MC. Hodgkin's lymphoma in a patient with Noonan syndrome with germ-line PTPN11 mutations. Int J Hematol. 2008;88(3):287-90.

34. Moore KL, Persaud TVN, Torchia MG. The developing human-E-book: clinically oriented embryology: Elsevier health sciences; 2018.

35. Nava C, Hanna N, Michot C, Pereira S, Pouvreau N, Niihori T, et al. Cardiofacio-cutaneous and Noonan syndromes due to mutations in the RAS/ MAPK signalling pathway: genotype-phenotype relationships and overlap with Costello syndrome. J Med Genet. 2007;44(12):763-71.

36. Bendon R, Asamoah A. Perinatal autopsy findings in three cases of jugular lymphatic obstruction sequence and cardiac polyvalvular dysplasia. Pediat Dev Pathol. 2008;11(2):133-7.

37. Mathur D, Somashekar S, Navarrete C, Rodriguez MM. Twin infant with lymphatic dysplasia diagnosed with Noonan syndrome by molecular genetic testing. Fetal Pediatr Pathol. 2014;33(4):253-7.

38. Tartaglia M, Mehler EL, Goldberg R, Zampino G, Brunner HG, Kremer H, et al. Mutations in PTPN11, encoding the protein tyrosine phosphatase SHP-2, cause Noonan syndrome. Nat Genet. 2001;29(4):465-8.

39. Gursu HA, Erdogan I, Varan B, Oktay A, Ozcay F, Ozkan M, et al. Oral budesonide as a therapy for protein-losing enteropathy in children after the Fontan operation. J Card Surg. 2014;29(5):712-6.

40. Hokari R, Kitagawa N, Watanabe C, Komoto S, Kurihara C, Okada Y, et al. Changes in regulatory molecules for lymphangiogenesis in intestinal lymphangiectasia with enteric protein loss. J Gastroenterol Hepatol. 2008; 23(7 Pt 2):e88-95.

41. Ranke MB, Lindberg A, Carlsson M, Camacho-Hubner C, Rooman R. Treatment with growth hormone in Noonan syndrome observed during 25 years of KIGS: near adult height and outcome prediction. Horm Res Paediatr. 2019;91(1):46-55. 
42. Alders M, Al-Gazali L, Cordeiro I, Dallapiccola B, Garavelli L, Tuysuz B, et al. Hennekam syndrome can be caused by FAT4 mutations and be allelic to Van Maldergem syndrome. Hum Genet. 2014;133(9):1161-7.

43. Alders M, Hogan BM, Gjini E, Salehi F, Al-Gazali L, Hennekam EA, et al. Mutations in CCBE1 cause generalized lymph vessel dysplasia in humans. Nat Genet. 2009:41(12):1272-4.

44. Sybert VP, McCauley E. Turner's syndrome. N Engl J Med. 2004;351(12): 1227-38.

\section{Publisher's Note}

Springer Nature remains neutral with regard to jurisdictional claims in published maps and institutional affiliations.

Ready to submit your research? Choose BMC and benefit from:

- fast, convenient online submission

- thorough peer review by experienced researchers in your field

- rapid publication on acceptance

- support for research data, including large and complex data types

- gold Open Access which fosters wider collaboration and increased citations

- maximum visibility for your research: over $100 \mathrm{M}$ website views per year

At $\mathrm{BMC}$, research is always in progress.

Learn more biomedcentral.com/submissions 